Cite this: RSC Adv., 2014, 4, 19703

Received 8th October 2013

Accepted 9th April 2014

DOI: 10.1039/c3ra45660a

www.rsc.org/advances

\section{Binding ability of first and second generation/ carbazolylphenyl dendrimers with Zn(II) tetraphenylporphyrin core towards small heterocyclic substrates $\uparrow$}

\author{
Nguyen Tran Nguyen, ${ }^{a}$ Galina M. Mamardashvili, ${ }^{b}$ Olga M. Kulikova, ${ }^{b}$

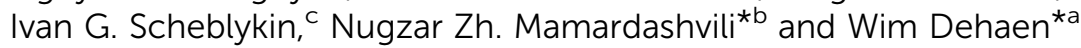

\begin{abstract}
A study of complex formation of Zn(॥) tetraarylporphyrin dendrimers with carbazolylphenyl branches towards 1,4-diazabicyclo-[2.2.2]octane, pyridine, imidazole, $N$-methylimidazole and 1,2,3-triazole was carried out by spectrophotometric and ${ }^{1} \mathrm{H}$ NMR titration methods. It has been shown that the binding ability of the porphyrin receptors towards mono and bidentate $\mathrm{N}$-containing substrates depends on the nature, number and generation of the branches. Bulky substituents are able either to significantly reduce the binding ability of the tetrapyrrolic cores due to the shielding of the porphyrin reaction centres, or to significantly increase it by forming intramolecular cavities for complementary binding of substrates. It has been determined that due to a good geometric match of the ligand's size with the size of the intramolecular cavities of the porphyrin receptors, and by the existence of additional hydrogen bonding and/or $\pi-\pi$ interactions between the ligand and the triazole fragments of the porphyrin the $\mathrm{Zn}$ tetraarylporphyrins with eight 4-carbazolylphenyl-1,2,3-triazole end groups of the first and the second generations could be used as effective receptors for imidazole, $N$-methylimidazole and 1,2,3-triazole. Taking into account the fact that binding is accompanied by a clear and easily identifiable response in the UV-Vis spectra of the reaction mixture, these metalloporphyrins could be considered as molecular optical sensing devices for small heterocyclic substrates.
\end{abstract}

\section{Introduction}

Dendrimers are monodisperse macromolecules with highly branched three-dimensional structures. Given the fact that the size of dendrimeric macromolecules can be predicted and controlled with a high accuracy they are often called a new generation of polymers and have a great future as polyfunctional materials. The presence of channels and pores allows them to encapsulate and/or activate small guest molecules, including physiologically active ones.

According with the literature, porphyrin-based dendrimers are of great interest. ${ }^{1-8}$ It was found that Fe(II) porphyrins containing polyethylenglycol branches have a much higher (1500 times) constant of reversible binding of $\mathrm{O}_{2}$ compared with

${ }^{a}$ Molecular Design and Synthesis, Department of Chemistry, $K U$ Leuven, Celestijnenlaan 200F, B-3001 Leuven, Belgium. E-mail: wim.dehaen@chem. kuleuven.be; Fax: +32 16 327990; Tel: +32 16327439

${ }^{b}$ Coordination Chemistry of Macrocyclic Compounds, G.A. Krestov Institute of Solution Chemistry of Russian Academy of Sciences, Akademicheskaya St.1, 153045 Ivanovo, Russia

${ }^{c}$ Lund University, Department of Chemical Physics, P.O. Box 124, 22100, Lund, Sweden $\dagger$ Electronic supplementary information (ESI) available. See DOI: 10.1039/c3ra45660a human hemoglobin in which the iron porphyrin (heme) is surrounded by a globular protein (globin). ${ }^{\mathbf{9}, 10}$ In both cases, the fixation of oxygen occurs as a result of its coordination at the iron atom. It is assumed that a causal factor responsible for the affinity of $\mathrm{O}_{2}$ to dendrimer porphyrins is the formation of hydrogen bonds between oxygen molecules and the amide groups of the branches' first generation. The design and properties of "patched dendrimers" has been described, ${ }^{\mathbf{1 1}}$ in which different types of oligopeptide dendrons are asymmetrically introduced on the $\mathrm{Zn}$ (II) porphyrin core. The "patch" gives the porphyrin dendrimer an additional interface to bind with another molecule or macromolecule. "patched dendrimers" with porphyrin cores show molecular recognition phenomena at the nanoscale, which provides good insight into the biological molecular recognition performed by proteins and enzymes.

Porphyrin-based dendrimers are often using as photofunctional artificial receptors, in which the strong photoabsorption and intense fluorescence signals of the porphyrin can respond sensitively to substrate binding. ${ }^{12-17}$

This paper investigates the binding ability of Zn-tetraarylporphyrins with different number [two (ZnD1-G1, ZnD4-G1, ZnD7-G2), four (ZnD2-G1, ZnD5-G1, ZnD8-G2) and eight (ZnD3G1, ZnD6-G1, ZnD9-G2)] and generation [the first (ZnD1-G1, 
ZnD2-G1，ZnD3-G1，ZnD4-G1，ZnD5-G1，ZnD6-G1) and the second (ZnD7-G2, ZnD8-G2, ZnD9-G2)] of carbazolylphenyl branches towards 1,4-diazabicyclo-[2.2.2]octane (L1), pyridine (L2), imidazole (L3), $N$-methylimidazole (L4) and 1,2,3-triazole (L5) in toluene. The dendrimers also differ by the nature of bridging spacers [oxygen (ZnD1-G1, ZnD2-G1, ZnD3-G1) and 1,2,3-triazole (ZnD4-G1, ZnD5-G1, ZnD6-G1, ZnD7-G2, ZnD8G2, ZnD9-G2)] connecting the tetraarylporphyrin core and carbazolylphenyl fragments. Zn(II) tetraphenylporphin (ZnTPP) was taken as the object of comparison. The compounds ZnD4G1，ZnD5-G1，ZnD6-G1，ZnD7-G2，ZnD8-G2，ZnD9-G2 were previously synthesized ${ }^{18}$ as new fluorescent switches and photoactive devices for detection of substrates of different nature.

\section{Result and discussion}

\section{Synthesis}

The synthesis of dendrimers $\mathbf{H}_{2}$ D1-G1, $\mathbf{H}_{2}$ D2-G1 and $\mathbf{H}_{2}$ D3-G1 was based on Lindsey method starting from 5-mesityldipyrromethane ${ }^{19}$ or pyrrole and carbazole-based aldehydes.

The nucleophilic substitution reaction of 4-(3,6-di-tert-butyl9H-carbazol-9-yl)phenol (1) ${ }^{20}$ and 4-bromomethylbenzaldehyde $(2)^{21}$ in DMF resulted in the formation of 4-[(4-(3,6-di-tert-butyl9H-carbazol-9-yl)phenoxy)methyl]benzaldehyde (3) (Scheme 1). Similarly, the mixture of arylaldehydes consisting of 3,5-bis(bromomethyl)-2,4,6-trimethylbenzaldehyde (4) and 3-bromomethyl-5-chloromethyl-2,4,6-trimethylbenzaldehyde $(5)^{18}$ was reacted with (1) and 3,5-bis[(4-(3,6-di-tert-butyl-9H-carbazol-9-yl)phenoxy)methyl]-2,4,6-trimethylbenzaldehyde (6) was obtained (Scheme 1) in pure form after column chromatography purification.

The condensation between arylaldehyde (3) and 5-mesityldipyrromethane ${ }^{19}$ was carried out in dry $\mathrm{CH}_{2} \mathrm{Cl}_{2}$ and the presence of a Lewis acid catalyst $\mathrm{BF}_{3} \cdot \mathrm{OEt}_{2}$ at room temperature. Then $p$-chloranil was used as oxidant and the reaction mixture was refluxed for 1 hour. The starting materials' concentration was optimized at $10 \mathrm{mM}$ in $\mathrm{CH}_{2} \mathrm{Cl}_{2}$, the yield of 5,15-bis(2,4,6trimethylphenyl)-10,20-bis[4-(4-(3,6-di-tert-butyl-9H-carbazol-9-yl)phenoxy)methylphenyl] porphyrin (7) (Scheme 2) reached $34 \%$

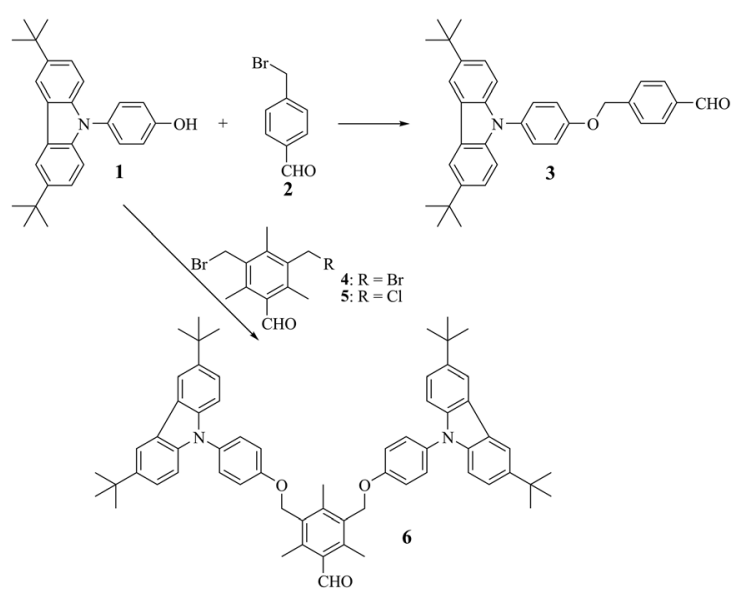

Scheme 1 Synthesis of carbazole-based aldehydes.
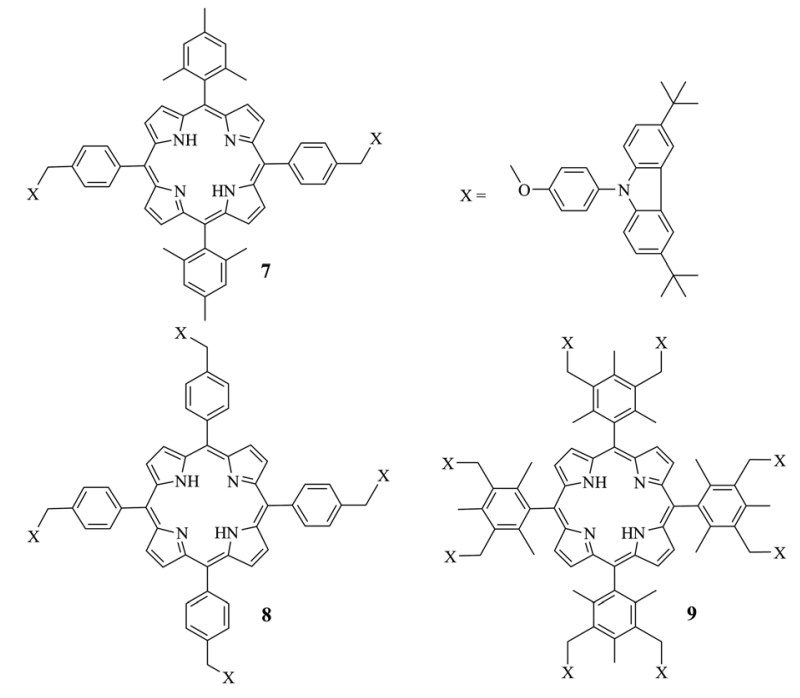

Scheme 2 Dendrimers $\mathrm{H}_{2}$ D1-G1 (7), $\mathrm{H}_{2}$ D2-G1 (8), $\mathrm{H}_{2}$ D3-G1 (9).

with 0.3 equivalent of $\mathrm{BF}_{3} \cdot \mathrm{OEt}_{2}$. Similarly, 5,10,15,20-tetrakis[4(4-(3,6-di-tert-butyl-9H-carbazol-9-yl)phenoxy)me-thylphenyl] porphyrin (8) was obtained in $15 \%$ when arylaldehyde (3) was reacted with pyrrole under the same conditions that were used to make dendrimer (7). The synthesis of 5,10,15,20-tetrakis[3,5bis((4-(3,6-di-tert-butyl-9H-carbazol-9-yl)-phenoxy)methyl)-2,4,6trimethylphenyl] porphyrin (9) was unsuccessful when using the procedure that applied for making dendrimer (7). In the presence of $0.75 \%$ absolute ethanol in dry $\mathrm{CH}_{2} \mathrm{Cl}_{2}$, the tetrasubstituted porphyrin (9) was obtained in 5\%. The increase in the amount of Lewis acid catalyst from 0.3 to 0.8 equivalent as well as the condensation time between (6) and pyrrole did not lead to any change in the yield of dendrimer (9). The low yield of making dendrimer (9) was due to the sterically hindered methyl groups at 2 and 6 positions and bulky groups at 3 and 5 positions of compound (6). Dendrimers (7), (8) and (9) were then metallated in $\mathrm{CHCl}_{3}$ to obtain ZnD1-G1, ZnD2-G1 and ZnD3-G1 in quantitative yield.

Dendrimers ZnD4-G1, ZnD5-G1, ZnD6-G1, ZnD7-G2, ZnD8G2, ZnD9-G2 (Scheme 3) were synthesized via the copper(I)catalyzed azide-alkyne cycloaddition (CuAAC reaction or click reaction) in THF solvent under $\left[\mathrm{Cu}\left(\mathrm{NCCH}_{3}\right)_{4}\right]\left[\mathrm{PF}_{6}\right]$ catalysis. ${ }^{18}$

\section{Binding ability}

The strength of axial binding of electron donating ligands (L) on $\mathrm{Zn}$ (II) porphyrins (ZnP) depends on the degree of aromaticity of the tetrapyrrolic macrocycle. ${ }^{22,23}$ The aromaticity of the tetrapyrrolic macrocycle is higher, the more strongly a zinc cation is connected with the macrocycle nitrogen atoms. The reasons of decreasing of the tetrapyrrolic macrocycle aromaticity can be both the electronic influence of the substituents, and a spatial factor causing distortion of the planar structure of the tetrapyrrolic macrocycle, especially due to unsymmetrical substitution with bulky substituents.

Next to distortion of the planar structure of the tetrapyrrolic macrocycle, bulky substituents can also create steric hindrance 


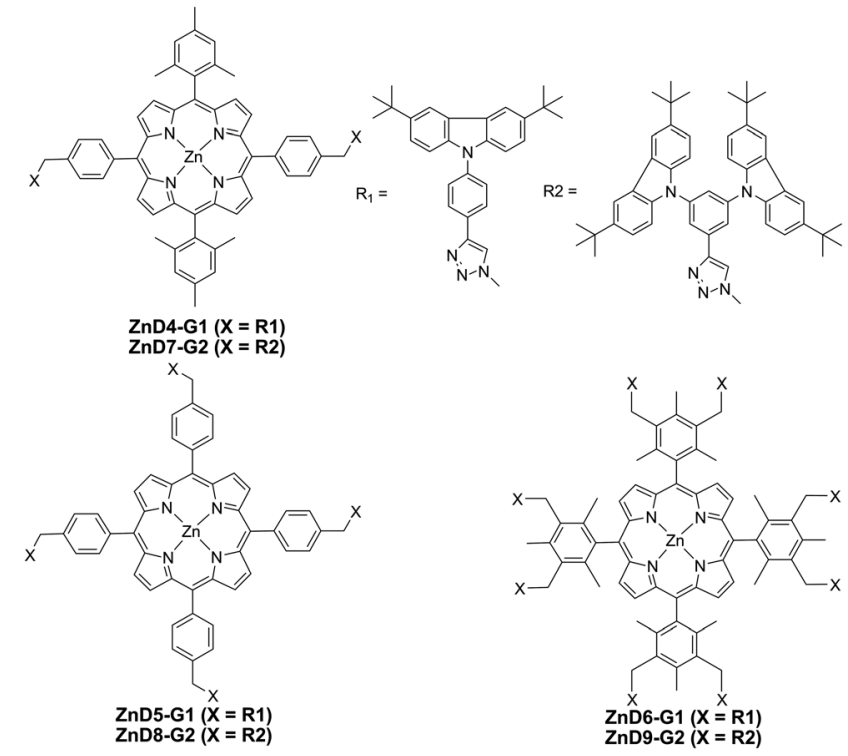

Scheme 3 Structures of dendrimers ZnD4-G1, ZnD5-G1, ZnD6-G1, ZnD7-G2, ZnD8-G2, ZnD9-G2.

to the ligands axial coordination due to shielding of the metalloporphyrin reaction center from both sides or a single side of the molecule. On the other hand, highly branched bulky substituents may form intramolecular binding cavities for effective binding of guest molecules.

Axial coordination of L1-L5 (Scheme 4) to ZnP is accompanied by a characteristic red shift of the absorption bands in the UV-Vis spectra of the system ZnP-L and a high field shift of the ligand protons signals in the ${ }^{1} \mathrm{H}$ NMR spectra of the corresponding complexes. It should be noted that upon complexation of ZnP with monodentate ligands L2-L5, over a wide concentration range of the ligands $\left(C_{\mathrm{L}}=1 \times 10^{-7}\right.$ to $8 \times$ $10^{-2} \mathrm{M}$ ), changes in the UV-Vis spectra of the reaction mixture occur with the formation of one family of spectral curves with one set of isosbestic points. The titration curve has one step, which indicates the formation of a single type of complexes in a ratio of $1: 1$. The details of the spectrophotometric and ${ }^{1} \mathrm{H}$ NMR titration are described in the preliminary communication. ${ }^{24}$ The changes in the UV-Vis spectra of the system ZnD3-G1-L3 and the corresponding binding isotherms are depicted on Fig. S1 as an example (ESI $\dagger$ ).

It was found that para-substitution of the tetrapyrrolic core phenyl groups by two (ZnD1-G1) or four (ZnD2-G1) 4-(4-(3,6bis(t-butyl)carbazol-9-ylphenyl)-oxy) fragments and by two (ZnD7-G2) or four (ZnD8-G2) 4-(4-(3,6-bis(t-butyl)carbazol-9ylphenyl)-1,2,3-triazole) branches of the second generation

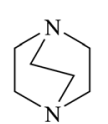<smiles>c1ccncc1</smiles><smiles>c1c[nH]cn1</smiles>

L1
L2

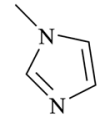

L3

L4

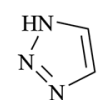

Scheme 4 Structures of ligands L1-L5. leads to an increase in the stability constants of the $1: 1$ complexes between the dendrimers (ZnD1-G1, ZnD2-G1, ZnD7G2, ZnD8-G2) and monodentate ligands L2-L5 as compared with the similar complexes of ZnTPP (Fig. S2 and Table 1) (ESI $\dagger$ ). This could be explained by distortion of the planar structure of the tetrapyrrolic macrocycle due to substitution with bulky groups.

The decreasing of the binding ability of the para-substituted porphyrins with two (ZnD4-G1) and four (ZnD5-G1) 4-(4-(3,6bis(t-butyl)carbazol-9-ylphenyl)-1,2,3-triazole) branches of the first generation as compared with the corresponding complexes of ZnTPP with L2-L5 $\mathbf{~}^{\mathbf{2 4}}$ probably is the result of shielding of the metalloporphyrin central zinc cation by one of the carbazolylphenyl fragments. The optimized structures of the dendrimers ZnD1-G1, ZnD4-G1 and ZnD7-G2 are given as an example of the validation of provided assumption on Fig. S3 (ESI $\dagger$ ). Tetrasubstituted dendrimers ZnD2-G1, ZnD5-G1 and ZnD8-G2 are characterized by the same features.

It should be noted that meta-octasubstitution of the tetrapyrrolic core phenyl groups by eight 4-(4-(3,6-bis(t-butyl)carbazol-9-ylphenyl)-1,2,3-triazole branches of the first (ZnD6-G1) and the second (ZnD9-G2) generations leads to an increase in the stability constants of the $1: 1$ complexes between the dendrimers and the monodentate ligands $\mathbf{L 2}-\mathbf{L 5}$ as compared with the similar complexes of ZnTPP and para-substituted dendrimers ZnD1-G1, ZnD2-G1, ZnD3-G1, ZnD4-G1, ZnD5-G1, ZnD7-G2, ZnD8-G2. ${ }^{24}$ As could be seen from Table 1, among the complexes of ZnD6-G1 with $\mathbf{L 2}-\mathbf{L} 5^{24}$ the complex between ZnD6G1 and L4 has the highest stability constant. This could be explained by a good geometric match of the ligand size to the size of the intramolecular cavities of the porphyrinic receptor. The decrease in the value of the binding constant of the complexes between ZnD9-G2 and $\mathbf{L 4}$ in comparison with the similar complexes of the dendrimer with $\mathbf{L} \mathbf{3}$ testifies that beside a good geometric match between host-guest molecules the formation of additional hydrogen bonding interactions between the $\mathbf{L} 3$ and the triazole fragments of ZnD9-G2 may be possible.

The dendrimers ZnD6-G1, ZnD9-G2 can be seen as a "picketfence" porphyrins with intramolecular cavities formed by the 4carbazolylphenyl-1,2,3-triazole end groups emanating from both sides of the porphyrin core (Fig. S4) (ESI†). ${ }^{24}$

Table 1 Stability constants of $1: 1$ complexes $\left(K_{\text {assoc }} 1, M^{-1}\right)$ between $\mathrm{ZnP}$ and monodentate ligands L2-L5 in toluene, $C_{\mathrm{ZnP}} \approx 1.1 \times 10^{-5} \mathrm{M}$

\begin{tabular}{lllll}
\hline & L2 & L3 & L4 & L5 \\
\hline ZnTPP & 5800 & 26460 & 39550 & 480 \\
ZnD1-G1 & 24180 & 120800 & 86900 & 8030 \\
ZnD2-G1 & 26400 & 118050 & 79500 & 11090 \\
ZnD3-G1 & 30500 & 250000 & 186300 & 87700 \\
ZnD4-G1 & 1200 & 7250 & 5050 & 90 \\
ZnD5-G1 & 3900 & 11700 & 8500 & 240 \\
ZnD6-G1 & 110000 & 545600 & 782500 & 660000 \\
ZnD7-G2 & 30530 & 70400 & 43000 & 9050 \\
ZnD8-G2 & 25000 & 80250 & 61800 & 15100 \\
ZnD9-G2 & 115000 & 600500 & 360000 & 810500
\end{tabular}


On the other hand, the meta-octasubstituted dendrimer ZnD3-G1 can not form similar intramolecular cavities for the ligand due to the lack of 1,2,3-triazole bridging fragments between tetrapyrrolic core and carbazolylphenyl branches. This is the reason why the binding ability of ZnD3-G1 towards L2-L5 is much less in comparison with ZnD6-G1, ${ }^{\mathbf{2 4}} \mathbf{Z n D 9 - G 2}$ and it is comparable while significantly higher than the corresponding values for ZnD1-G1, ZnD2-G1 (Table 1). The dependence of the stability constants of octa-substituted dendrimers ZnD3-G1, ZnD6-G1, ZnD9-G2 with L2-L5 on the nature of small N-containing organic molecules is summarized in Fig. 1.

In line with our interests in the supramolecular chemistry of porphyrins, ${ }^{25-28}$ we also investigated the binding ability of ZnD1G1, ZnD2-G1, ZnD3-G1, ZnD4-G1, ZnD5-G1, ZnD6-G1, ZnD7-G2, ZnD8-G2, ZnD9-G2 ${ }^{24}$ towards the bidentate ligand L1. It is well known that upon interaction of $\mathbf{Z n P}$ with bifunctional nitrogen containing ligands formation of the complexes in a ratio of either $1: 1$ or $2: 1$ is possible. ${ }^{29-31}$ Spatially distorted porphyrins or porphyrins with bulky substituents do not form complexes with $\mathbf{L 1}$ in a ratio of $2: 1$.

The study of complex formation of dendrimers with two (ZnD1-G1, ZnD4-G1, ZnD7-G2) and four (ZnD2-G1, ZnD5-G1, ZnD8-G2) branches and the octa-substituted dendrimer ZnD3G1 without 1,2,3-triazole bridging groups between the tetrapyrrolic core and the carbazolylphenyl fragments with $\mathbf{L 1}$, using the method of spectrophotometric titration, showed that these processes, similarly to the system $\mathbf{Z n P}-\mathbf{L 1}$, proceed in two

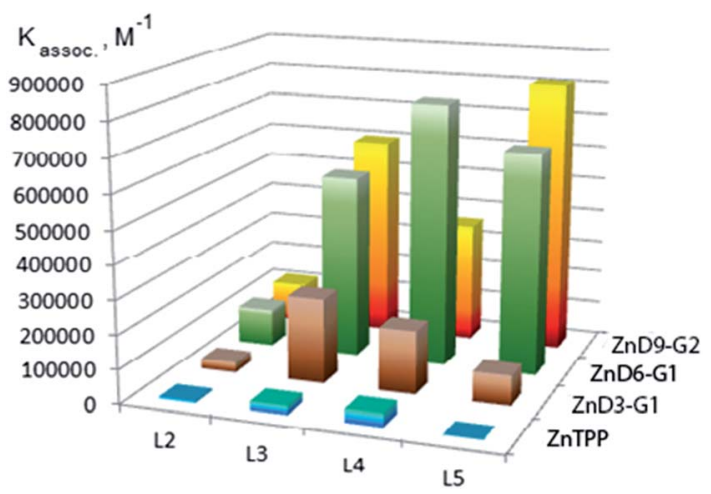

Fig. 1 Stability constants of ZnTPP and octa-substituted dendrimers with L2-L5 in toluene, $25^{\circ} \mathrm{C}$.

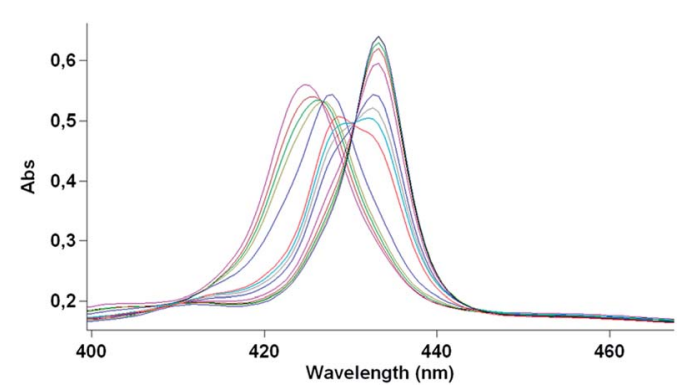

Fig. 2 The changes in the UV-Vis spectra of the system ZnD3-G1-L1 in toluene at $20^{\circ} \mathrm{C}, C_{Z n D 3-G 1}=0$ to $1.0 \times 10^{-4} \mathrm{M}$.
Table 2 The stability constants of $1: 1$ and $2: 1$ complexes of $\mathrm{ZnP}$ with bidentate ligand $\mathrm{L} 1$ in toluene at $25^{\circ} \mathrm{C}, \mathrm{C}_{\mathrm{ZnP}} \approx 1.5 \times 10^{-5} \mathrm{M}^{a}$

\begin{tabular}{lll}
\hline & $2: 1$ complexes, & $1: 1$ complexes, \\
& $K_{\text {assoc } 2},\left(\mathrm{M}^{-2}\right)$ & $K_{\text {assoc } 1,}\left(\mathrm{M}^{-1}\right)$ \\
\hline ZnTPP & $5.0 \times 10^{9}$ & $1.9 \times 10^{5}$ \\
ZnD1-G1 & $6.0 \times 10^{9}$ & $2.1 \times 10^{5}$ \\
ZnD2-G1 & $6.0 \times 10^{9}$ & $2.2 \times 10^{5}$ \\
ZnD3-G1 & $4.0 \times 10^{10}$ & $2.1 \times 10^{5}$ \\
ZnD4-G1 & $1.7 \times 10^{8}$ & $2.3 \times 10^{4}$ \\
ZnD5-G1 & $1.3 \times 10^{9}$ & $9.7 \times 10^{4}$ \\
ZnD6-G1 & - & $1.3 \times 10^{6}$ \\
ZnD7-G2 & $7.0 \times 10^{9}$ & $2.1 \times 10^{5}$ \\
ZnD8-G2 & $8.0 \times 10^{9}$ & $2.9 \times 10^{5}$ \\
ZnD9-G2 & - & $7.4 \times 10^{5}$
\end{tabular}

${ }^{a}$ The error in determining the stability constants was $5-7 \%$ (for $1: 1$ complexes) and 10\% (for $2: 1$ complexes).

stages. The changes in the UV-Vis spectra of the system ZnD3G1-L1 in toluene are depicted in Fig. 2 as an example.

There are two families of spectral curves with two sets of isosbestic points in the UV-Vis spectra of the system. Each of them is characterized by its own step in the corresponding titration curves (Fig. S5 and S6) (ESI $\dagger$ ). Existence of two steps in the complexation also is confirmed by the graphical dependence of $\lg \left[\left(A_{0}-A_{\mathrm{i}}\right) /\left(A_{\mathrm{i}}-A_{\mathrm{k}}\right)\right]$ from $\lg C_{\mathrm{L}}$ for the system. The splitting of the ligand non-equivalent proton signal in the ${ }^{1} \mathrm{H}$ NMR spectrum of the complex formed at the high concentrations of the ligand according with the literature ${ }^{25-28}$ indicates the formation of a $1: 1$ complex. One signal of the ligand equivalent protons in the spectrum of the complex at lower concentrations of the ligand reveals the formation of the $2: 1$ complex between ZnD3-G1 and L1.

It should be noted that complex formation of dendrimers ZnD6-G1 ${ }^{24}$ ZnD9-G2 with $\mathbf{L 1}$ in toluene proceeds in a single step with the formation of only $1: 1$ complexes. Probably, the presence of the bulky branches in the first and second generations prevents two-center coordination of L1. The stability constants of the considered complexes are presented in Table 2.

\section{Conclusions}

Thus, the study of complex formation of $\mathrm{Zn}$ (II) tetraarylporphyrins with carbazolylphenyl branches by spectrophotometric and ${ }^{1} \mathrm{H}$ NMR titration methods showed that their binding ability towards mono and bidentate $\mathrm{N}$-containing organic molecules depends on the nature, number and generation of the branches. Bulky substituents are able either to significantly reduce the binding ability of the tetrapyrrolic cores due to the shielding of the porphyrin reaction centers, or significantly increase it by forming of intramolecular cavities for complementary binding of substrates. By varying the number of the branches and the number of their generation, it is possible to develop intramolecular cavities of different shapes for selective binding of guest molecules by a good geometric match of the ligand size to the size of the cavities, and by a existence of 
additional $\pi-\pi$ and/or hydrogen bonding interactions between the ligand and the triazole fragments of the porphyrin. These metalloporphyrins could be considered as a molecular optical sensing device for small heterocyclic substrates due to a clear and easily identifiable response in the UV-Vis spectra of the reaction mixture.

\section{Experimental}

\section{General experimental methods}

NMR spectra were acquired on commercial instruments (Bruker Avance $300 \mathrm{MHz}$, Bruker AMX $400 \mathrm{MHz}$ or Bruker Avance $\mathrm{II}^{+}$ $600 \mathrm{MHz})$ and chemical shifts $(\delta)$ are reported in parts per million (ppm) referenced to tetramethylsilane (TMS) or the internal (NMR) solvent signals. Mass spectra were run using a HP5989A apparatus (CI and EI, $70 \mathrm{eV}$ ionisation energy) with Apollo 300 data system or a Thermo Finnigan LCQ advantage apparatus (ESI). Exact mass measurements were acquired on a Kratos MS50TC instrument (performed in the EI mode at a resolution of 10000 ). Melting points (not corrected) were determined using a Reichert Thermovar apparatus. For column chromatography, 70-230 mesh silica 60 (E. M. Merck) was used as the stationary phase. Chemicals received from commercial sources were used without further purification. MALDI-TOF mass spectrometry was carried out on Bruker Daltonics ultraflex II \& ultraflex II TOF/TOF using the matrix 2,5-dihydroxylbenzoic acid for all samples.

Spectroscopic methods and instrumentation. 1,4-Diazabicyclo-[2.2.2] octane (L1), pyridine (L2), imidazole (L3), $N$-methylimidazole (L4) and 1,2,3-triazole (L5) from SigmaAldrich were used without further purification. ${ }^{1} \mathrm{H}$ NMR spectra were recorded on a Bruker VC-500 (500.17 MHz) in $\mathrm{CDCl}_{3}$ using TMS as the internal standard. UV-Vis spectra of the porphyrins and their evolution upon addition of the ligands were measured on a Carry 100 spectrophotometer.

The UV-visible absorption spectral studies reveal red shifted Soret and visible bands upon addition of the ligands to a solution of the investigated receptor porphyrins confirming that the $\mathrm{N}$-containing entity of the ligands binds to the $\mathrm{Zn}$ cation of the coordination centre of the tetrapyrrolic macrocycle.

The stability constants of the metalloporphyrin complexes with the ligands in ratio of $1: 1\left(K_{\text {assoc } 1}\right)$ and $2: 1\left(K_{\text {assoc } 2}\right)$ were calculated according with the literature ${ }^{17}$ based on spectrophotometric data at two wavelengths (decreasing and increasing) using the following relationships:

$$
\begin{gathered}
K_{\mathrm{assoc} 1}=\frac{[\mathrm{A}-\mathrm{B}]}{[\mathrm{A}][\mathrm{B}]}=1 /[\mathrm{B}]\left(\frac{\Delta A_{\mathrm{i}, \lambda_{1}}}{\Delta A_{\mathrm{o}, \lambda_{1}}} \frac{\Delta A_{\mathrm{o}, \lambda_{2}}}{\Delta A_{\mathrm{i}, \lambda_{2}}}\right), \quad \mathrm{M}^{-1} \\
K_{\mathrm{assoc} 2}=\frac{[\mathrm{A}-\mathrm{B}-\mathrm{A}]}{[\mathrm{A}]^{2}[\mathrm{~B}]}=1 /[\mathrm{A}][\mathrm{B}]\left(\frac{\Delta A_{\mathrm{i}, \lambda_{1}}}{\Delta A_{\mathrm{o}, \lambda_{1}}} \frac{\Delta A_{\mathrm{o}, \lambda_{2}}}{\Delta A_{\mathrm{i}, \lambda_{2}}}\right), \quad \mathrm{M}^{-2}
\end{gathered}
$$

where, $\lambda_{1}$ is the decreasing wavelength, $\lambda_{2}$ is the increasing wavelength, [A] is the Zn-porphyrin concentration, [B] is the ligand concentration, $\Delta \mathrm{A}_{\mathrm{o}}$ is the maximal change of the optical density at the given wavelength, $\Delta \mathrm{A}_{\mathrm{i}}-$ is the change of the optical density of the solution at a given wavelength at a given concentration.

Synthesis of 4-[(4-(3,6-di-tert-butyl-9H-carbazol-9-yl)phenoxy)methyl]benzaldehyde (3). 4-Bromomethylbenzaldehyde (2) (200 mg, $1.1 \mathrm{mmol}, 1$ equiv.) and 4-(3,6-di-tert-butyl-9H-carbazol-9-yl)phenol (1) were stirred in DMF $(10 \mathrm{ml})$ for a few minutes. Then $\mathrm{K}_{2} \mathrm{CO}_{3}$ was added and the reaction was conducted at $80{ }^{\circ} \mathrm{C}$ overnight under $\mathrm{N}_{2}$ atmosphere. Crude product was purified by column chromatography (silica, eluent $\mathrm{CH}_{2} \mathrm{Cl}_{2}-$ heptane $2: 1$ ) to obtain (3) (366 mg, 73\%) as a white solid. M.p. 190-192 ${ }^{\circ} \mathrm{C} .{ }^{1} \mathrm{H}$ NMR (300 MHz, $\left.\mathrm{CDCl}_{3}, 25{ }^{\circ} \mathrm{C}, \mathrm{TMS}\right): \delta=10.05$ (s, 1H, CHO), 8.13 (s, 2H, H-carbazole), $7.95\left(\mathrm{~d},{ }^{3} J_{\mathrm{H}, \mathrm{H}}=7.92,2 \mathrm{H}\right.$, $\mathrm{H}-\mathrm{Ar}), 7.66\left(\mathrm{~d},{ }^{3} J_{\mathrm{H}, \mathrm{H}}=7.89,2 \mathrm{H}, \mathrm{H}-\mathrm{Ar}\right), 7.44\left(\mathrm{~d},{ }^{3} \mathrm{~J}_{\mathrm{H}, \mathrm{H}}=8.67,4 \mathrm{H}\right.$, $\mathrm{H}-\mathrm{Ar}), 7.25\left(\mathrm{~d},{ }^{3} \mathrm{~J}_{\mathrm{H}, \mathrm{H}}=8.49,2 \mathrm{H}, \mathrm{H}-\mathrm{Ar}\right), 7.14\left(\mathrm{~d},{ }^{3} J_{\mathrm{H}, \mathrm{H}}=8.64,2 \mathrm{H}\right.$, $\mathrm{H}-\mathrm{Ar}$ ), $1.45 \mathrm{ppm}$ (s, 18H, tert-butyl). ${ }^{13} \mathrm{C} \mathrm{NMR} \mathrm{(75} \mathrm{MHz,} \mathrm{CDCl}_{3}$, $\left.25{ }^{\circ} \mathrm{C}, \mathrm{TMS}\right): \delta=191.86,130.14,128.34,127.58,123.53,116.21$, 115.88, 109.03 (CH-Ar), 157.25, 143.69, 142.60, 139.63, 136.09, 131.48, 123.08 ppm (C-Ar), $69.57\left(\mathrm{CH}_{2}\right), 34.71$ (C, tert-butyl), $32.02 \mathrm{ppm}\left(\mathrm{CH}_{3}\right.$, tert-butyl). HRMS (EI): $\mathrm{m} / \mathrm{z}$ calcd for $\mathrm{C}_{34} \mathrm{H}_{35} \mathrm{NO}_{2}$ : $489.27\left[\mathrm{M}^{+}\right]$; found $489.26\left[\mathrm{M}^{+}\right]$.

Synthesis of 3,5-bis[(4-(3,6-di-tert-butyl-9H-carbazol-9-yl)phenoxy)methyl]-2,4,6-trimethylbenzaldehyde (6). The mixture of arylaldehydes (180 mg), consisting of 3,5-bis(bromomethyl)2,4,6-trimethylbenzaldehyde (4) and 3-bromomethyl-5-chloromethyl-2,4,6-trimethylbenzaldehyde (5), and carbazole-based phenol (1) were dissolved in DMF (10 ml) and the mixture was stirred at room temperature for a few minutes. Subsequently, $\mathrm{K}_{2} \mathrm{CO}_{3}(148 \mathrm{mg}, 1.08 \mathrm{mmol})$ and a catalytic amount of 18-crown$6(26.4 \mathrm{mg}, 0.1 \mathrm{mmol}$ ) were added and the reaction was carried out at $80{ }^{\circ} \mathrm{C}$ overnight under $\mathrm{N}_{2}$ atmosphere. Purification was conducted via a silica column $\left(\mathrm{CH}_{2} \mathrm{Cl}_{2}\right.$-heptane1.5: 1) to obtain (6) (390 mg) as a white solid. M.p. $268-270{ }^{\circ} \mathrm{C} .{ }^{1} \mathrm{H}$ NMR $(300$ $\left.\mathrm{MHz}^{\mathrm{CDCl}} \mathrm{CD}_{3}, 2{ }^{\circ} \mathrm{C}, \mathrm{TMS}\right): \delta=10.72(\mathrm{~s}, 1 \mathrm{H}, \mathrm{CHO}), 8.14$ (s, 4H, Hcarbazole), $7.48\left(\mathrm{~m}, 8 \mathrm{H}, \mathrm{H}\right.$-carbazole), $7.29\left(\mathrm{~d},{ }^{3} \mathrm{~J}_{\mathrm{H}, \mathrm{H}}=8.64,4 \mathrm{H}\right.$, $\mathrm{H}-\mathrm{Ar}$ ), 7.21 (d, $\left.{ }^{3} J_{\mathrm{H}, \mathrm{H}}=8.67,4 \mathrm{H}, \mathrm{H}-\mathrm{Ar}\right), 5.22\left(\mathrm{~s}, 4 \mathrm{H}, \mathrm{CH}_{2}\right), 2.66$ $\left(\mathrm{s}, 6 \mathrm{H}, 2 \times \mathrm{CH}_{3}\right), 2.62\left(\mathrm{~s}, 3 \mathrm{H}, \mathrm{CH}_{3}\right), 1.46 \mathrm{ppm}$ (s, 36H, tert-butyl). ${ }^{13} \mathrm{C}$ NMR (75 MHz, $\mathrm{CDCl}_{3}, 25{ }^{\circ} \mathrm{C}$, TMS): $\delta=195.33$ (CHO), 128.34, 123.51, 116.21, 115.64, 109.05 (CH-Ar), 157.76, 143.63, 142.60, 140.26, 139.68, 134.01, 132.51, 131.42, 123.09 (C-Ar), $64.48\left(\mathrm{CH}_{2}\right), 34.72$ (C, tert-butyl), $32.04\left(\mathrm{CH}_{3}\right.$, tert-butyl), 16.58 $\left(\mathrm{CH}_{3}\right), 15.89$ ppm $\left(\mathrm{CH}_{3}\right)$. MALDI-TOF: $\mathrm{m} / z$ calcd for $\mathrm{C}_{64} \mathrm{H}_{70} \mathrm{~N}_{2} \mathrm{O}_{3}$ : $914.54\left[\mathrm{M}^{+}\right]$; found $914.53\left[\mathrm{M}^{+}\right]$.

Synthesis of 5,15-bis(2,4,6-trimethylphenyl)-10,20-bis[4-(4(3,6-di-tert-butyl-9H-carbazol-9-yl)phenoxy)methylphenyl] porphyrin (7). Arylaldehyde (3) (100 mg, $0.20 \mathrm{mmol}, 1$ equiv.) and 5-mesityldipyrromethane (54 $\mathrm{mg}, 0.20 \mathrm{mmol}, 1$ equiv.) were dissolved in dry $\mathrm{CH}_{2} \mathrm{Cl}_{2}(20 \mathrm{ml})$ and the solution was purged with $\mathrm{N}_{2}$ for a few minutes. Then $\mathrm{BF}_{3} \cdot \mathrm{OEt}_{2}(7.5 \mu \mathrm{l}, 0.06 \mathrm{mmol}$, 0.3 equiv.), in dry $\mathrm{CH}_{2} \mathrm{Cl}_{2}(1 \mathrm{ml})$, was added dropwise and the resulting solution was stirred at room temperature for 1 hour under $\mathrm{N}_{2}$ atmosphere. Subsequently, $p$-chloranil (100 mg, $0.41 \mathrm{mmol}, 2$ equiv.) was added in powder form and the mixture was heated at reflux for 1 hour. The solvent was evaporated and then purification was carried out with column chromatography. The first flash column (silica, eluent $\mathrm{CH}_{2} \mathrm{Cl}_{2}$ ) was to remove dark pigments and the second one (silicagel, $\mathrm{CH}_{2} \mathrm{Cl}_{2}$-heptane $1: 1.5)$ was to separate the different porphyrin fractions. Pure 
product (51 mg, 34\%) was obtained as a purple solid. ${ }^{1} \mathrm{H}$ NMR (300 MHz, $\left.\mathrm{CDCl}_{3}, 25^{\circ} \mathrm{C}, \mathrm{TMS}\right): \delta=8.84\left(\mathrm{~d},{ }^{3} \mathrm{~J}_{\mathrm{H}, \mathrm{H}}=4.71,4 \mathrm{H}, \mathrm{H}-\right.$ pyrrole), 8.71 (d, ${ }^{3} J_{\mathrm{H}, \mathrm{H}}=4.5,4 \mathrm{H}, \mathrm{H}$-pyrrole), $8.29\left(\mathrm{~d},{ }^{3} J_{\mathrm{H}, \mathrm{H}}=7.71\right.$, $4 \mathrm{H}, \mathrm{H}-\mathrm{Ar}$ ), 8.17 (s, 4H, H-carbazole), 7.87 (d, ${ }^{3} J_{\mathrm{H}, \mathrm{H}}=7.74,4 \mathrm{H}, \mathrm{H}-$ $\mathrm{Ar}), 7.56\left(\mathrm{~d},{ }^{3} \mathrm{~J}_{\mathrm{H}, \mathrm{H}}=8.46,4 \mathrm{H}, \mathrm{H}-\mathrm{Ar}\right), 7.49\left(\mathrm{~d},{ }^{3} \mathrm{~J}_{\mathrm{H}, \mathrm{H}}=8.64,4 \mathrm{H}, \mathrm{H}-\right.$ $\mathrm{Ar}$ ), 7.36 (m, 8H, H-Ar), 7.29 (s, 4H, H-mesityl), 5.50 (s, 4H, $2 \times$ $\left.\mathrm{CH}_{2}\right), 2.63\left(\mathrm{~s}, 6 \mathrm{H}, 2 \times \mathrm{CH}_{3}\right), 1.85\left(\mathrm{~s}, 12 \mathrm{H}, 4 \times \mathrm{CH}_{3}\right), 1.48(\mathrm{~s}, 36 \mathrm{H}$, tert-butyl), $-2.59 \mathrm{ppm}(\mathrm{s}, 2 \mathrm{H}, 2 \times \mathrm{NH}) .{ }^{13} \mathrm{C} \mathrm{NMR}(75 \mathrm{MHz}$, $\mathrm{CDCl}_{3}, 25{ }^{\circ} \mathrm{C}$, TMS): $\delta=134.77,128.40,127.78,125.94,123.54$, 116.20, 116.04, 109.12 (CH-Ar), 157.88, 142.56, 141.88, 139.75, 139.39, 138.40, 137.76, 136.16, 131.31, 123.10, 118.86, 118.42 (CAr), $70.50\left(\mathrm{CH}_{2}\right), 34.74$ (C, tert-butyl), $32.06\left(\mathrm{CH}_{3}\right.$, tert-butyl), $21.65\left(\mathrm{CH}_{3}\right), 21.48 \mathrm{ppm}\left(\mathrm{CH}_{3}\right)$. MALDI-TOF: $\mathrm{m} / \mathrm{z}$ calcd for $\mathrm{C}_{104} \mathrm{H}_{100} \mathrm{~N}_{6} \mathrm{O}_{2}: 1465.94\left[\mathrm{M}^{+}\right]$; found $1465.84\left[\mathrm{M}^{+}\right]$.

Synthesis of $5,10,15,20$-tetrakis[4-(4-(3,6-di-tert-butyl-9Hcarbazol-9-yl)phenoxy)methylphenyl] porphyrin (8). Compound (3) was reacted with pyrrole under $\mathrm{BF}_{3} \cdot \mathrm{OEt}_{2}$ catalysis using the procedure that was applied for the synthesis of dendrimer D1 (7). Crude product was purified by column chromatography (silica, $\mathrm{CH}_{2} \mathrm{Cl}_{2}$-heptane $1: 1$ ) to get pure compound (15\%) as a purple solid. ${ }^{1} \mathrm{H}$ NMR (300 $\left.\mathrm{MHz}, \mathrm{CDCl}_{3}, 25{ }^{\circ} \mathrm{C}, \mathrm{TMS}\right): \delta=8.92$ (s, 8H, H-pyrrole), 8.28 (d, $\left.{ }^{3} J_{\mathrm{H}, \mathrm{H}}=7.71 \mathrm{~Hz}, 8 \mathrm{H}, \mathrm{H}-\mathrm{Ar}\right), 8.17(\mathrm{~s}, 8 \mathrm{H}$, H-carbazole), 7.86 (d, $\left.{ }^{3} J_{\mathrm{H}, \mathrm{H}}=7.71 \mathrm{~Hz}, 8 \mathrm{H}, \mathrm{H}-\mathrm{Ar}\right), 7.55\left(\mathrm{~d},{ }^{3} \mathrm{~J}_{\mathrm{H}, \mathrm{H}}=\right.$ $8.46 \mathrm{~Hz}, 8 \mathrm{H}, \mathrm{H}-\mathrm{Ar}$ ), 7.49 (d, ${ }^{3} J_{\mathrm{H}, \mathrm{H}}=8.67 \mathrm{~Hz}, 8 \mathrm{H}, \mathrm{H}-\mathrm{Ar}$ ), 7.35 $\left(\mathrm{d},{ }^{3} \mathrm{~J}_{\mathrm{H}, \mathrm{H}}=8.64 \mathrm{~Hz}, 16 \mathrm{H}, \mathrm{H}-\mathrm{Ar}\right), 5.45\left(\mathrm{~s}, 8 \mathrm{H}, \mathrm{CH}_{2}\right), 1.48(\mathrm{~s}, 72 \mathrm{H}$, tert-butyl), $-2.70 \mathrm{ppm}(\mathrm{s}, 2 \mathrm{H}, 2 \times \mathrm{NH}) .{ }^{13} \mathrm{C}$ NMR $(75 \mathrm{MHz}$, $\mathrm{CDCl}_{3}, 25{ }^{\circ} \mathrm{C}$, TMS): $\delta=134.83,128.38,125.98,123.55,116.21$, 116.00, 109.12 (CH-Ar), 157.86, 142.57, 141.95, 139.73, 136.27, 131.31, 123.10, 119.82 (C-Ar), $70.42\left(\mathrm{CH}_{2}\right), 34.73$ (C, tert-butyl), $32.05\left(\mathrm{CH}_{3}\right.$, tert-butyl). MALDI-TOF: $m / z$ calcd for $\mathrm{C}_{152} \mathrm{H}_{146} \mathrm{~N}_{8} \mathrm{O}_{4}$ : $2148.84\left[\mathrm{M}^{+}\right]$; found $2148.30\left[\mathrm{M}^{+}\right]$.

Synthesis of 5,10,15,20-tetrakis[3,5-bis((4-(3,6-di-tert-butyl-9Hcarbazol-9-yl)phenoxy)methyl)-2,4,6-trimethylphenyl] porphyrin (9). 3,5-Bis[(4-(3,6-di-tert-butyl-9H-carbazol-9-yl)phenoxy)methyl]2,4,6-trimethylbenzaldehyde (6) (200 mg, $0.21 \mathrm{mmol}, 1$ equiv.) and pyrrole $\left(15 \mu \mathrm{l}, 0.21 \mathrm{mmol}, 1\right.$ equiv.) were dissolved in $\mathrm{CH}_{2} \mathrm{Cl}_{2}$ $(22 \mathrm{ml})$ and absolute ethanol $(164 \mu \mathrm{l})$. The solution was purged with $\mathrm{N}_{2}$ for 15 minutes. The reaction was carried out following the procedure described above using $\mathrm{BF}_{3} \cdot \mathrm{OEt}_{2}$ ( 0.3 equiv.). Crude product was purified by column chromatography (silica, $\mathrm{CH}_{2} \mathrm{Cl}_{2}-$ heptane $1: 1)$ to get pure compound $(10 \mathrm{mg}, 5 \%)$ as a purple solid. ${ }^{1} \mathrm{H}$ NMR (600 MHz, $\left.\mathrm{CDCl}_{3}, 25{ }^{\circ} \mathrm{C}, \mathrm{TMS}\right): \delta=8.82\left(\mathrm{~s}_{\mathrm{br}}, 8 \mathrm{H}, \mathrm{H}-\right.$ pyrrole), 8.10 (s, 16H, H-carbazole), 7.48 ( $\left.\mathrm{s}_{\mathrm{br}}, 16 \mathrm{H}, \mathrm{H}-\mathrm{Ar}\right), 7.39$ (d, $\left.{ }^{3} J_{\mathrm{H}, \mathrm{H}}=7.74 \mathrm{~Hz}, 16 \mathrm{H}, \mathrm{H}-\mathrm{Ar}\right), 7.32\left(\mathrm{~s}_{\mathrm{br}}, 16 \mathrm{H}, \mathrm{H}-\mathrm{Ar}\right), 7.25$ (s, 16H, H$\mathrm{Ar}), 5.46\left(\mathrm{~s}_{\mathrm{br}}, 16 \mathrm{H}, \mathrm{CH}_{2}\right), 2.93\left(\mathrm{~s}, 12 \mathrm{H}, \mathrm{CH}_{3}\right), 2.05\left(\mathrm{~s}_{\mathrm{br}}, 24 \mathrm{H}, \mathrm{CH}_{3}\right)$, $1.41 \mathrm{ppm}\left(\mathrm{s}, 144 \mathrm{H}\right.$, tert-butyl). ${ }^{13} \mathrm{C} \mathrm{NMR}\left(100 \mathrm{MHz}, \mathrm{CDCl}_{3}, 25{ }^{\circ} \mathrm{C}\right.$, TMS): $\delta=158.15,144.97,142.55,140.91,140.16,139.72,131.27$, 130.96, 128.35, 123.47, 123.07, 116.16, 115.77, 109.08 (C, CH-Ar), $65.86\left(\mathrm{CH}_{2}\right), 34.68$ (C, tert-butyl), $32.00\left(\mathrm{CH}_{3}\right.$, tert-butyl), 19.32 $\left(\mathrm{CH}_{3}\right), 16.33$ ppm $\left(\mathrm{CH}_{3}\right)$. MALDI-TOF: $\mathrm{m} / \mathrm{z}$ calcd for $\mathrm{C}_{272} \mathrm{H}_{286} \mathrm{~N}_{12} \mathrm{O}_{8}$ : $3851.26\left[\mathrm{M}^{+}\right]$; found $3851.58\left[\mathrm{M}^{+}\right]$.

\section{General procedure for synthesis of zinc(II) porphyrin}

Porphyrin (15 mg, 1 equiv.) and $\mathrm{Zn}(\mathrm{OAc})_{2} \cdot \mathrm{H}_{2} \mathrm{O}$ (4 equiv.) were added to a flask of $25 \mathrm{ml}$ containing $\mathrm{CHCl}_{3}(10 \mathrm{ml})$ and the solution was heated at reflux for 4 hours. The resulting mixture was washed three times with distilled water. The organic layer was dried over $\mathrm{MgSO}_{4}$ and the solvent was evaporated under vacuum to obtain $\mathrm{Zn}$ (II)-porphyrin in pure form in quantitative yield.

Dendrimer ZnD1-G1. ${ }^{1} \mathrm{H}$ NMR $\left(300 \mathrm{MHz}, \mathrm{CDCl}_{3}, 25^{\circ} \mathrm{C}, \mathrm{TMS}\right)$ : $\delta=8.93\left(\mathrm{~d},{ }^{3} J_{\mathrm{H}, \mathrm{H}}=4.71 \mathrm{~Hz}, 4 \mathrm{H}, \mathrm{H}\right.$-pyrrole $), 8.80\left(\mathrm{~d},{ }^{3} J_{\mathrm{H}, \mathrm{H}}=4.71\right.$ $\mathrm{Hz}, 4 \mathrm{H}, \mathrm{H}-$ pyrrole), 8.30 (d, $\left.{ }^{3} J_{\mathrm{H}, \mathrm{H}}=7.92 \mathrm{~Hz}, 4 \mathrm{H}, \mathrm{H}-\mathrm{Ar}\right), 8.17$ (d, ${ }^{4} J_{\mathrm{H}, \mathrm{H}}=1.5 \mathrm{~Hz}, 4 \mathrm{H}, \mathrm{H}$-carbazole $), 7.86\left(\mathrm{~d},{ }^{3} J_{\mathrm{H}, \mathrm{H}}=7.92 \mathrm{~Hz}, 4 \mathrm{H}, \mathrm{H}-\right.$ $\mathrm{Ar}), 7.56\left(\mathrm{~d},{ }^{3} J_{\mathrm{H}, \mathrm{H}}=8.85 \mathrm{~Hz}, 4 \mathrm{H}, \mathrm{H}-\mathrm{Ar}\right), 7.49\left(\mathrm{dd},{ }^{3} J_{\mathrm{H}, \mathrm{H}}=8.67 \mathrm{~Hz}\right.$, $\left.{ }^{4} J_{\mathrm{H}, \mathrm{H}}=1.71 \mathrm{~Hz}, 4 \mathrm{H}, \mathrm{H}-\mathrm{Ar}\right), 7.35\left(\mathrm{dd},{ }^{3} J_{\mathrm{H}, \mathrm{H}}=8.85 \mathrm{~Hz},{ }^{4} J_{\mathrm{H}, \mathrm{H}}=2.46\right.$ $\mathrm{Hz}, 8 \mathrm{H}, \mathrm{H}-\mathrm{Ar}$ ), 7.28 (s, 4H, H-mesityl), 5.48 (s, 4H, $\mathrm{CH}_{2}$ ), 2.63 (s, $\left.6 \mathrm{H}, \mathrm{CH}_{3}\right), 1.84\left(\mathrm{~s}, 12 \mathrm{H}, \mathrm{CH}_{3}\right), 1.48 \mathrm{ppm}$ (s, 36H, tert-butyl). ${ }^{13} \mathrm{C}$ NMR (75 MHz, $\mathrm{CDCl}_{3}, 25{ }^{\circ} \mathrm{C}$, TMS): $\delta=134.68,132.33,130.85$, 128.38, 127.68, 125.80, 123.55, 116.20, 116.06, 109.14 (CH-Ar), 157.89, 150.04, 149.98, 142.68, 142.56, 139.75, 139.24, 138.99, 137.49, 135.87, 131.29, 123.10, 119.78, 119.39 (C-Ar), 70.57 $\left(\mathrm{CH}_{2}\right), 34.74 \mathrm{ppm}$ (C, tert-butyl). MALDI-TOF: $\mathrm{m} / \mathrm{z}$ calcd for $\mathrm{C}_{104} \mathrm{H}_{98} \mathrm{~N}_{6} \mathrm{O}_{2} \mathrm{Zn:} 1527.71\left[\mathrm{M}^{+}\right]$; found $1527.78\left[\mathrm{M}^{+}\right]$.

Dendrimer ZnD2-G1. ${ }^{1} \mathrm{H}$ NMR (300 $\mathrm{MHz}, \mathrm{CDCl}_{3}, 25{ }^{\circ} \mathrm{C}$, TMS): $\delta=9.03$ (s, 8H, H-pyrrole), 8.30 (d, ${ }^{3} \mathrm{~J}_{\mathrm{H}, \mathrm{H}}=7.71 \mathrm{~Hz}, 8 \mathrm{H}, \mathrm{H}-\mathrm{Ar}$ ), $8.17\left(\mathrm{~d},{ }^{4} J_{\mathrm{H}, \mathrm{H}}=1.29 \mathrm{~Hz}, 8 \mathrm{H}, \mathrm{H}\right.$-carbazole $), 7.88\left(\mathrm{~d},{ }^{3} J_{\mathrm{H}, \mathrm{H}}=7.92\right.$ $\mathrm{Hz}, 8 \mathrm{H}, \mathrm{H}-\mathrm{Ar}$ ), 7.56 (d, $\left.{ }^{3} J_{\mathrm{H}, \mathrm{H}}=8.67 \mathrm{~Hz}, 8 \mathrm{H}, \mathrm{H}-\mathrm{Ar}\right), 7.49$ (dd, ${ }^{3} J_{\mathrm{H}, \mathrm{H}}$ $\left.=8.67 \mathrm{~Hz},{ }^{4} J_{\mathrm{H}, \mathrm{H}}=1.68 \mathrm{~Hz}, 8 \mathrm{H}, \mathrm{H}-\mathrm{Ar}\right), 7.35\left(\mathrm{dd},{ }^{3} J_{\mathrm{H}, \mathrm{H}}=8.64 \mathrm{~Hz}\right.$, $\left.{ }^{4} J_{\mathrm{H}, \mathrm{H}}=2.46 \mathrm{~Hz}, 16 \mathrm{H}, \mathrm{H}-\mathrm{Ar}\right), 5.48\left(\mathrm{~s}, 8 \mathrm{H}, \mathrm{CH}_{2}\right), 1.48$ (s, 72H, tertbutyl). ${ }^{13} \mathrm{C}$ NMR (75 MHz, $\left.\mathrm{CDCl}_{3}, 25{ }^{\circ} \mathrm{C}, \mathrm{TMS}\right): \delta=134.70$, 132.13, 128.38, 125.87, 123.54, 116.21, 116.03, 109.12 (CH-Ar), 157.89, 150.24, 142.65, 142.57, 139.75, 136.02, 131.31, 123.11, 120.80 (C-Ar), $70.54\left(\mathrm{CH}_{2}\right), 34.73$ (C, tert-butyl), $32.05\left(\mathrm{CH}_{3}\right.$, tertbutyl). MALDI-TOF: $m / z$ calcd for $\mathrm{C}_{152} \mathrm{H}_{144} \mathrm{~N}_{8} \mathrm{O}_{4} \mathrm{Zn}: 2210.06\left[\mathrm{M}^{+}\right]$; found $2210.28\left[\mathrm{M}^{+}\right]$.

Dendrimer ZnD3-G1. ${ }^{1} \mathrm{H}$ NMR (600 MHz, $\mathrm{CDCl}_{3}, 25^{\circ} \mathrm{C}$, TMS): $\delta=8.88$ ( $\mathrm{s}_{\mathrm{br}}, 8 \mathrm{H}, \mathrm{H}$-pyrrole), 8.12 (s, 16H, H-pyrrole), 7.50 (d, $\left.{ }^{3} J_{\mathrm{H}, \mathrm{H}}=8.1 \mathrm{~Hz}, 16 \mathrm{H}, \mathrm{H}-\mathrm{Ar}\right), 7.40\left(\mathrm{~d},{ }^{3} J_{\mathrm{H}, \mathrm{H}}=8.82 \mathrm{~Hz}, 16 \mathrm{H}, \mathrm{H}-\mathrm{Ar}\right.$ ), $7.32\left(\mathrm{~s}_{\mathrm{br}}, 16 \mathrm{H}, \mathrm{H}-\mathrm{Ar}\right), 7.27$ (d, $\left.{ }^{3} J_{\mathrm{H}, \mathrm{H}}=8.82 \mathrm{~Hz}, 16 \mathrm{H}, \mathrm{H}-\mathrm{Ar}\right), 5.48$ $\left(\mathrm{s}_{\mathrm{br}}, 16 \mathrm{H}, \mathrm{CH}_{2}\right), 2.95\left(\mathrm{~s}, 12 \mathrm{H}, \mathrm{CH}_{3}\right), 2.05\left(\mathrm{~s}_{\mathrm{br}}, 24 \mathrm{H}, \mathrm{CH}_{3}\right), 1.43(\mathrm{~s}$, 144H, tert-butyl). ${ }^{13} \mathrm{C}$ NMR (100 MHz, $\left.\mathrm{CDCl}_{3}, 25{ }^{\circ} \mathrm{C}, \mathrm{TMS}\right): \delta=$ 128.34, 123.47, 116.17, 115.79, 109.09 (CH-Ar), 158.20, 150.08, $142.55,140.72,139.73,131.44,131.25,130.80,123.09$, (C-Ar), $65.94\left(\mathrm{CH}_{2}\right), 34.68$ (C, tert-butyl), $32.01\left(\mathrm{CH}_{3}\right.$, tert-butyl), 19.27 $\left(\mathrm{CH}_{3}\right), 16.30$ ppm $\left(\mathrm{CH}_{3}\right)$. MALDI-TOF: $\mathrm{m} / \mathrm{z}$ calcd for $\mathrm{C}_{272} \mathrm{H}_{284} \mathrm{~N}_{12} \mathrm{O}_{8} \mathrm{Zn}$ : $3912.15\left[\mathrm{M}^{+}\right]$; found $3912.26\left[\mathrm{M}^{+}\right]$.

\section{Acknowledgements}

This work was supported by a FP-7 grant from the EC for Research, Technological Development and Demonstration Activities, "Dendrimers for Photonic Devices" IRSES-PEOPLE2009-247260-DphotoD, under the "International Research Staff Exchange Scheme". Nguyen Tran Nguyen thanks Ministry of Education and Training, Vietnam International Education Development (VIED) for financial support during his Ph.D in KU Leuven, Belgium.

\section{Notes and references}

1 H. Azho, L. Baldini, J. Hong, A. J. Wilson and A. D. Hamilton, J. Am. Chem. Soc., 2006, 128, 2421-2425. 
2 P. Weyermann, J.-P. Gisselbrecht, C. Boudon, F. Diederich and M. Gross, Angew. Chem., Int. Ed., 1999, 38, 3212-3215.

3 H. S. Park, Q. Lin and A. D. Hamilton, J. Am. Chem. Soc., 1999, 121, 8-13.

4 A. Zingg, B. Felber, L. Fu, J. P. Collman and F. Diederich, Helv. Chim. Acta, 2002, 85, 333-351.

5 P. Weyermann and F. Diederich, Helv. Chim. Acta, 2002, 85, 599.

6 G. J. Hawker and J. M. J. Fréchet, J. Am. Chem. Soc., 1990, 112, 7638-7647.

7 R. H. Jin, T. Aida and S. Inoue, Chem. Commun., 1993, 12601262.

8 Y. Tomoyose, D. L. Jiang, R. H. Jin, T. Aida, T. Yamashita, K. Horie, E. Yashima and Y. Okamoto, Macromolecules, 1996, 29, 5236-5238.

9 P. J. Dandliker, F. Diederich and J.-P. Gisselbrecht, Angew. Chem. Int., Ed. Engl., 1995, 34, 2775.

10 J. P. Collman, L. Fu, A. Zingg and F. Diederrich, Chem. Commun., 1997, 193-194.

11 S. Shinoda, J. Inclusion Phenom. Macrocyclic Chem., 2007, 59, 1-9.

12 K. Maurer, K. Hager and A. Hirsch, Eur. J. Org. Chem., 2006, 3338-3347.

13 G. L. Hawker and J. M. J. Frechet, J. Am. Chem. Soc., 1990, 112, 7638-7647.

14 J. Kress, A. Rosner and A. Hirsch, Chem.-Eur. J., 2000, 6, 247257.

15 B. Buschhaus, W. Bauer and A. Hirsch, Tetrahedron, 2003, 59, 3899-3915.

16 B. Buschhaus and A. Hirsch, Eur. J. Org. Chem., 2005, 11481160.

17 B. Buschhaus, F. Hampel, S. Grimme and A. Hirsch, Chem.Eur. J., 2005, 11, 3530-3540.
18 N. T. Nguyen, J. Hofkens, I. Scheblykin, M. Kruk and W. Dehaen, Eur. J. Org. Chem., 2014, 1766-1777.

19 T. Rohand, E. Dolusic, T. H. Ngo, W. Maes and W. Dehaen, ARKIVOC, 2007, 307-324.

20 Z.-H. Zhao, H. Jin, Y.-X. Zhang, Z. Shen, D.-C. Zou and X.-H. Fan, Macromolecules, 2011, 44, 1405-1413.

21 J.-M. Barbe, G. Canard, S. Brandes and R. Guilard, Eur. J. Org. Chem., 2005, 21, 4601-4611.

22 G. M. Mamardashvili, I. A. Shinkar, N. Zh. Mamardashvili and O. I. Koifman, Russ. J. Coord. Chem., 2007, 33(10), 774778.

23 N. Zh. Mamardashvili and O. I. Koifman, Russ. J. Org. Chem., 2005, 41(6), 807-826.

24 N. T. Nguyen, G. Mamardashvili, M. Gruzdev, N. Mamardashvili and W. Dehaen, Supramol. Chem., 2013, 25(3), 180-188.

25 G. M. Mamardashvili, N. Zh. Mamardashvili and O. I. Koifman, Russ. J. Inorg. Chem., 2007, 52(8), 1215.

26 G. M. Mamardashvili, O. M. Kulikova, N. Zh. Mamardashvili and O. I. Koifman, Russ. J. Coord. Chem., 2008, 34(6), 427433.

27 G. M. Mamardashvili, O. M. Kulikova and O. I. Koifman, Russ. J. Gen. Chem., 2007, 77(11), 1965-1971.

28 G. M. Mamardashvili, O. M. Kulikova, N. Zh. Mamardashvili and O. I. Koifman, Russ. J. Gen. Chem., 2008, 78(10), 19641971.

29 V. V. Borovkov and Y. Inoue, Top. Curr. Chem., 2006, 265, 89146.

30 V. V. Borovkov, N. Zh. Mamardashvili and Y. Inoue, Russ. Chem. Rev., 2006, 75, 737-748.

31 B. C. Kavaric, B. Kokona, A. D. Shwab, M. A. Twomey, J. C. Paula and R. Faiman, J. Am. Chem. Soc., 2006, 128, 4166-4167. 